\title{
A Brief Review of Recent Nanotechnological and Pharmacological Potentials with Special Reference to Plectranthus amboinicus
}

\author{
Surya Gundu \\ Department of Zoology, Karnatak University, Dharwad-580003, India \\ E-mail: suryavgundu[at]gmail.com
}

\begin{abstract}
Plectranthus amboinicus an excellent medicinal plant species belongs to the family Lamiaceae known to cure many diseases. Tribal people used plants as medicine without scientific knowledge but scientists still searching curative drugs for many immunological and biological diseases. Although it is essential to know the toxicological data with respect to particular plant species as they have different chemical constituents. Plectranthus amboinicus is also known as Indian borage, having unique medicinal properties it was the most important species in plant world. Present survey focuses on Nanoparticle, Ethno-medicinal, Toxicological aspects of Plectranthus amboinicus and to create research thrust in these areas.
\end{abstract}

Keywords: Plectranthus amboinicus; Pharmacological applications; Nanoparticles; Phytochemicals; Toxic effects

\section{Introduction}

Toxins are one of the most important biomolecules of life, as they can kill harmful bacteria or Cancer cells at right doses and at the same time it can harm host cell upon wrong doses of the same toxin [2, 4]. According to Paracelsus "All substances are poisonous, there is none that is not a poison, the right dose differentiates a poison from a remedy" [1].Every single plant or animal produces biochemical toxins to protect themselves by predators either it may be bacteria or other organism. Plants produce most dangerous chemicals called "Phytotoxins" that have biomedical applications in animal world. Alkaloids in combination with other chemicals affect the organism in a toxic way but it will act as a best drug when alkaloid alone used [3].

Population explosion and unhygienic conditions in India has led many people prone to diseases like diarrhea, cholera, typhoid, [12, 13] etc. In order to control these diseases pharmacological industry made a robust impact in Human society. Synthetic drugs more are toxic than herbal drugs as herbal drugs contain a number of phytochemical mixtures whereas synthetic drugs contain a single chemical formulation, many times people die because of the high dosage of synthetic drugs and the immune response of the human body against it $[14,15]$. To improve accuracy and effective drug delivery pharmacologists moved towards a new era of Phytomedical world, now scientists formulating drugs using plant resources in variety of forms.

Plectranthus amboinicus is an aromatic shrub and Medicinal plant that belongs to the family lamiaceae widely distributed in tropical Africa, Asia and Australia [6]. The leaves are fleshy, tomentose in nature [Figure 2], Plectranthus genus is known to produce many bioactive compounds like flavonoids, saponins, tannins, steroids, volatile oils and terpinoids [5]. In India the plant is used as food, medicine, and aerosol in tribal communities. Nutrition is the main aspect of living organisms which plays an important role in Diet, containing $0.26 \%$ iron, $1.56 \%$ insoluble dietary fibers, proteins, vitamins and beta carotene as a major components $P$. amboinicus is a highly nutritious plant $[7,41,42]$.

People are more dependent \& attracted towards nature, World Health Organization estimated that more than $80 \%$ people dependent on plant and their extracts for better health management with reduced cost and side effects $[9,10]$. Phytochemicals are the chemicals produced by plants as a result of metabolism or catabolism, to resist some ecological conditions; $P$. amboinicus contain 76 volatile [carvacrol and thymol] and 30 non-volatile [sesquiterpene hydrocarbons, monoterpene hydrocarbons, flavonoids, oxygenated monoterpenes and esters] compounds making itself a potential phytochemical manufacturer in its family [11]

\subsection{Taxonomy of Plectranthus amboinicus}

Domain: Eukaryote

Kingdom: Plantae

Phylum: Spermatophyta

Subphylum: Angiospermae

Class: Dicotyledonae

Order: Lamiales

Family: Lamiaceae

Genus: Plectranthus

Species: Plectranthus amboinicus

1.2 List of Chemical compounds obtained from Plectranthus amboinicus plant

\begin{tabular}{|c|c|}
\hline Chemical class of compounds & Compound name \\
\cline { 2 - 2 } & 5-hydroxy-7,4'-dimethoxyflavone \\
\cline { 2 - 3 } Flavonoids & 5-hydroxy-7,3',4'-trimethoxyflavone \\
\cline { 2 - 3 } & $5,3^{\prime}$-dihydroxy-7,4'-dimethoxyflavone \\
\cline { 2 - 3 } & $5,4^{\prime}$-dihydroxy-7,3'-dimethoxyflavone \\
\hline
\end{tabular}

Volume 9 Issue 12, December 2020 
International Journal of Science and Research (IJSR)

ISSN: 2319-7064

SJIF (2019): 7.583

\begin{tabular}{|c|c|}
\hline \multirow{3}{*}{ Benzenoids } & Vanillic acid \\
\hline & P-hydroxybenzoic acid \\
\hline & Methylparaben \\
\hline Quinol & 4-acetonyl-3,5-dimethoxy-p-quinol \\
\hline \multirow{3}{*}{ Steroids } & $\beta$-sitosterol \\
\hline & $\beta$-sitostenone \\
\hline & stigmastenone \\
\hline Lignan & (+)-syringaresinol \\
\hline \multirow{21}{*}{ Terpene } & Myrcene \\
\hline & $\alpha$-Pinene \\
\hline & Linalool \\
\hline & $\alpha$-Terpinolene \\
\hline & $\alpha$-terpinene \\
\hline & $\alpha$-Terpineol \\
\hline & Thymol \\
\hline & Carvacrol \\
\hline & Terpinen-1-ol-4 \\
\hline & Camphor \\
\hline & Limonene \\
\hline & (Z)-beta-ocimene \\
\hline & (E)- $\beta$-ocimene \\
\hline & $\alpha$-Phelandrène \\
\hline & $\gamma$-Terpinene \\
\hline & p-Cymene \\
\hline & $\beta$-pinene \\
\hline & calamenol \\
\hline & delta-3-Carene \\
\hline & $\alpha$-Phellandrene \\
\hline & Camphene \\
\hline \multirow{16}{*}{ Sesquiterpene } & $\beta$-cubebene \\
\hline & $4 \beta, 7 \beta$-Aromadendrene Diol \\
\hline & Farnesol \\
\hline & $\beta$-bisabolene \\
\hline & delta-cadinene \\
\hline & Caryophyllene oxide \\
\hline & $(-) \alpha$-Selinene \\
\hline & $\alpha$-Cadinol \\
\hline & $\delta$-Cadinol \\
\hline & $\beta$-Guaiene \\
\hline & $\alpha$-humulene \\
\hline & (Z)- $\beta$-Farnesene \\
\hline & a-Bergamotene \\
\hline & $\beta$-caryophyllene \\
\hline & $\beta$-Elemene \\
\hline & a-Cubebene \\
\hline Alcohol & 1-Octen-3-ol \\
\hline
\end{tabular}

1.3: Percentage of compounds extracted from Plectranthus amboinicus

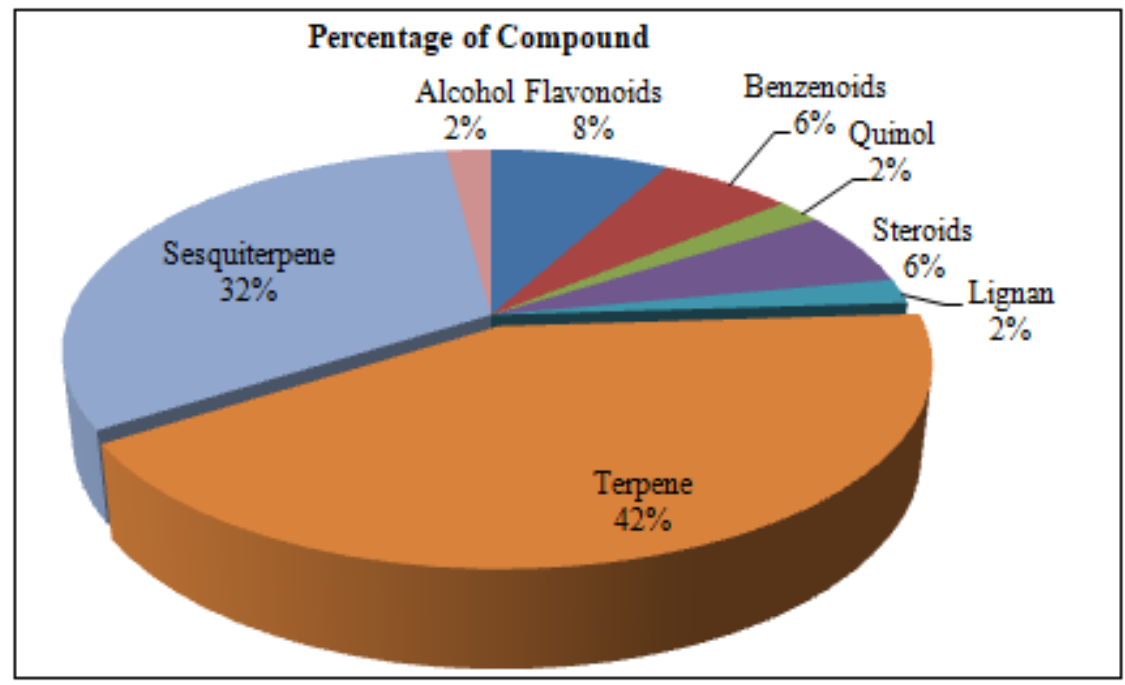

Volume 9 Issue 12, December 2020

www.ijsr.net

Licensed Under Creative Commons Attribution CC BY 


\section{Materials and methods}

Our literature survey included peer review of scientific research papers, interpretation of results and conclusions. Throughout our survey we used many research search engine tools like Science direct, Google scholar, j-gate,
Research gate, Citeseerx etc and also visited for the plant identification etc.

\subsection{Photograph of Plectranthus amboinicus}

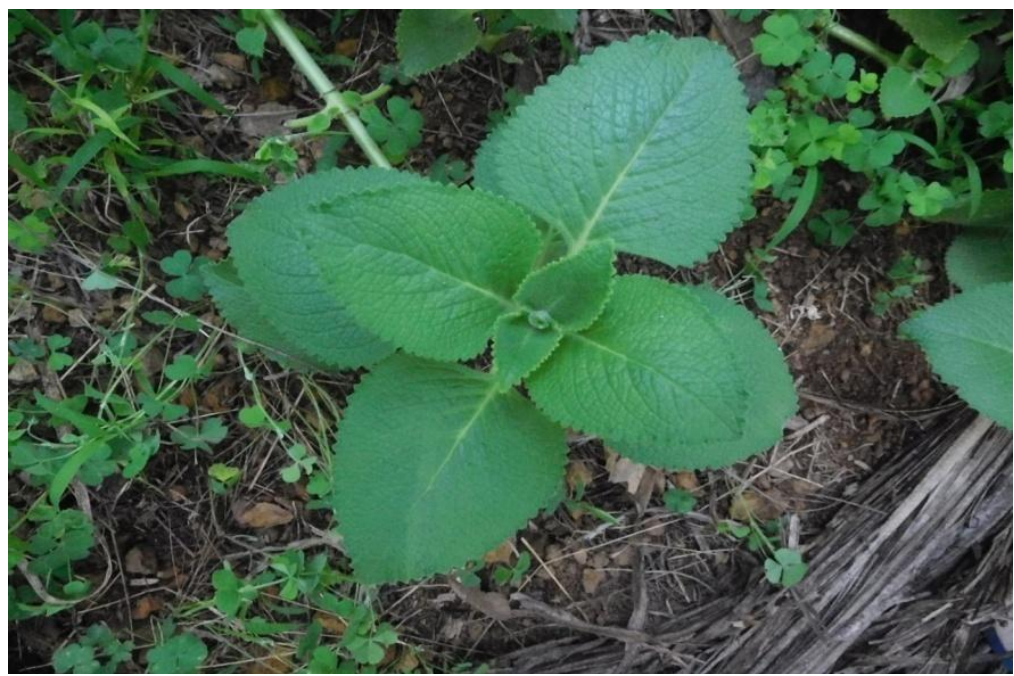

\section{Toxic effects of Plectranthus amboinicus}

Major part of plant is leaves, most of the chemicals produce in the leaf itself, extraction of chemicals from leaf shown many toxicological properties, Patricia Fontes Pinheiro et al [16] assessed cytotoxic effects on $L$. sativawhich resulted in chromosomal alterations. The $\mathrm{LC}_{50}$ of Larval and Pupal toxicity to four stages of Aedes aegypti was found to be $26.12,35.36,45.76,52.32$ and $63.82 \mathrm{ppm}$ respectively which show strong larvicidal effects [17]. Aqueous extract of dose 25 and $50 \mathrm{mg} / \mathrm{ml}$ effectively inhibited $37 \%$ \& $57 \%$ root growth of Allium cepa by cytotoxic activities [18].

\section{Applications of Plectranthus amboinicus Nanoparticles}

Nanoparticle was the most recently used drug delivery system in Pharmacological studies, using plant materials such as Leaf, Stem, Root, Fruit, etc. [Figure 2]. the Nanoparticles can be synthesized with proper protocols \& utilizing metals like $\mathrm{AgNO}_{3}, \mathrm{ZnO}$. Nanoparticles were used in many industries including Textiles for the degradation process of many dyes; biosynthesized $\mathrm{ZnO}$ nanoparticles of $P$. amboinicus had shown degradation of Methyl red dye, and $\mathrm{SnO}$ biosynthesized Nanoparticle expressed degradation of Rhodamine B dye [19, 22]larvicidal activites at the concentration of 8 and $10 \mu \mathrm{g} / \mathrm{ml}$ against Mosquito larvae of Anopheles stephensi, Culex quinquefasciatus, and Culex tritaeniorhynchuswas shown by $\mathrm{ZnO}$ Nanoparticles[21].Silver has vital role in antimicrobial activity; this activity was increased by using plant extract of $P$. amboinicus, the synthesized nanoparticle displayed antimicrobial activity against E. coli, Penicillium spp. [20]. Methylene blue dye degradation was shown by $\mathrm{Ag}$ Nanoparticles and confirmed by instrumental techniques [23]. Nanoparticles had become advanced over traditional drugs exhibiting antiproliferative activity on T47D breastcancer cells via apoptotic pathway [24].

\section{Pharmacological Applications}

Most of the plants used in pharmacology are to improve human welfare; P.amboinicuswas reported having Antioxidant \& Nephroprotective properties against Adriamycin induced acute toxicity in Male Wister rats at a dose of $400 \mathrm{mg} / \mathrm{kg}$ body weight, Antilithiotic activities was observed at a dose of $500 \mathrm{mg} / \mathrm{kg}$ juice of leaf extract in 35-day study [25, 26, 31]. Inflammation is Rapid immune response against pathogens upon injury, in vitro \& in vivo antiinflammatory and analgesic activities of $P$. amboinicus aqueous extract was effective at doses $0.5 \& 1.0 \mathrm{~g}$ [27, 33].Anti-inflammatory, Anticancer activity on Paw edema and sarcoma-180, Ehrlich ascite carcinoma cells respectively shown by crude Hydro-alcoholic extracts in Female albino rats and mice at a dose of 100, 150, 250, \& $300 \mathrm{mg} / \mathrm{kg}$ [28], an experimental ethanolic extract dose of $300,600,900 \mathrm{mg} / \mathrm{kg}$ expressed Hepatoprotective activity against paracetamol induced hepatotoxicity [29]. Diuretic activity, anti-gastric ulcer activity was found at doses of $500 \mathrm{mg} / \mathrm{kg} \& 200 \mathrm{mg} / \mathrm{kg}$ in Wister rats $[30,32]$.

Diabetes the most affecting disorder in humankind, antihyperglycemic and antihyperlipidemic activities of P.amboinicus extracts is a promising basis for antidiabetic drug discovery [34]. Antianxiety effect, Immunostimulatory effect, antibacterial, antifungicidal activity, Expectorant activity was reported on this plant species [35, 36, 37].

The actual mechanism behind anti-inflammatory activity was revealed by Jih-Hwa Guh et al. the research shown that P.amboinicusextract inhibits release of interleukin $1 B$ through which antiinflammation was activated [39].High Antibacterial activity over Klebsiella pneumonia was recorded for the chloroform and Methanolic extract of the plant [40].

\section{Volume 9 Issue 12, December 2020}




\section{Discussion}

The world is full of plants, Humans greatly dependent on plants for daily needs. $P$. amboinicus is one of such plant in which human is benefited, it is also used in spicy foods in China \& India. Because of its medicinal value many researches have done using plant extracts. Extraction of chemicals from plant sources include many sequential isolating steps using broad range of solvents like Methanol, Ethanol, Aqueous, Hydro-alcoholic extractions etc. The principle behind the use of solvents is that many Phytochemicals soluble in polar or nonpolar solvents according to their chemical nature. In this survey Toxicological research indicated cytotoxic effect and larvicidal activities, Pharmacological studies shown Antioxidative, Antihyperlipidemic, Antihyperglycemic, Antilithiotic, Immunostimulatory, Diuretic, Antiinflammatory, Nephroprotective, Hepatoprotective, Anticancer activities, and Nanoparticle studies resulted data related to Antibacterial and Antiproliferative effects on various bacteria and cells. It indicates the high potency of a single plant species from Plectranthus genera.

\section{Conclusion}

The present survey focused species-specific data related to Plectranthus amboinicus, apart from medicinal uses the plant species lacking toxicological data like toxic effect on insects, toxicological endpoint for organisms, because the plant is capable of producing many types of alkaloids and terpenes. In Nanoparticle synthesis the plant is used for basic research \& still more research has to be done related to emerging recent era of Nanopesticide fields. Biosynthesized nanoparticles show high degree of effect compare to solvent extracts.

\section{References}

[1] Cutris D. Klaassen., John B. Watkins III.(2015).Casarett\&Doull's Essentials of Toxicology $3^{\text {rd }}$ edition.McGraw-Hill Companies. Page-2

[2] Balachandran P, Rajgopal G.(2005).Cancer-an ayurvedic perspective. Pharm Res. 51(1):19-30.

[3] Maryam Moudi, Rusea Go, Christina Yong Seok Yien, and Mohd. (2013). Vinca Alkaloids NazreInt J Prev Med. Nov4(11), 1231-1235.

[4] D. Diker a, D. Markovitz a, M. Rothman b, U. Sendovski. (2007). Coma as a presenting sign of Datura stramonium seed tea poisoning.European Journal of Internal Medicine 18, 336-338.

[5] Abdel-Mogib M, Albar HA, Batterjee SM.(2002). Chemistry of genus Plectranthus. Molecules. 7, 271301.

[6] Lukhoba, C. W., Simmonds, M. S., \& Paton, A. J. (2006). Plectranthus: a review of ethnobotanical uses. Journal of Ethnopharmacology, 103, 1-24.

[7] Om Prakash Rout et al. (2012). Pathorchur (coleus aromaticus): a review of the medicinal evidence for its phytochemistry and pharmacology properties. 3:4.

[8] Arumugam, G. Swamy, M.K.Sinniah U.R. (2016). Plectranthus amboinicus (Lour.) Spreng: Botanical,
Phytochemical, Pharmacological and Nutritional Significance. Molecules 21, 369.

[9] Swamy, M.K.; Sinniah, U.R. (2015). A comprehensive review on the phytochemical constituents and pharmacological activities of PogostemoncablinBenth.: An aromatic medicinal plant of industrial importance. Molecules 20, 8521-8547.

[10] Sandhya, S. Kumar, S.P. Vinod, K.R. David, B. Kumar, K. (2011). Plants as potent anti-diabetic and wound healing agents: A review. Hygeia. J. Drugs Med. 3, 11-19.

[11] Greetha Arumugam, Mallappa Kumara Swamy. and Uma Rani Sinniah. (2016). Plectranthus amboinicus (Lour.) Spreng: Botanical, Phytochemical, Pharmacological and Nutritional Significance., Molecules 21:369, 1-26.

[12] SubithaLakshminarayanan and Ramakrishnan Jayalakshmy. (2015). Diarrheal diseases among children in India: Current scenario and future Perspectives. J Nat Sci Biol Med. 6:1, 24-28.

[13] NSDeodhar(2003) Epidemiological perspective of domestic and personal hygiene in India, International Journal of Environmental Health Research, 13:1, 4756. DOI: 10.1080/0960312031000102796.

[14] Ali Karimi, MaedehMajlesi, and Mahmoud RafieianKopaei. (2015).Herbal versus synthetic drugs; beliefs and facts., J Nephropharmacol. 4:1, 27-30.

[15] Prescription drug overdoses: A review. (2012).Journal of Safety Research 43:4, 283-289.

[16] S.M.KRates. (2001). Plants as source of drugs. Toxicon39:5, 603-613.

[17] Patrícia Fontes Pinheiro et al. (2015). Phytotoxicity and Cytotoxicity of Essential Oil from Leaves of Plectranthus amboinicus, Carvacrol, and Thymol in Plant Bioassays. J. Agric. Food Chem. 63:41, 89818990.

[18] Murugan, K., Kalimuthu, K., Mahesh Kumar, P. et al.(2013).Phytoparasitica $41: \quad 307$. https://doi.org/10.1007/s12600-013-0291-3

[19] LiFu., ZhuxianFu. (2015). Plectranthus amboinicus leaf extract-assisted biosynthesis of $\mathrm{ZnO}$ nanoparticles and their photo catalytic activity. Ceramics International41:2, Part A, 2492-2496.

[20] B.Ajitha., Y.Ashok Kumar Reddy., P.Sreedhara Reddy. (2014). Biosynthesis of silver nanoparticles using Plectranthus amboinicus leaf extract and its antimicrobial activity., Spectrochimica Acta Part A: Molecular and Biomolecular Spectroscopy128, 257262.

[21] B.Vaseeharan et al. (2015). Plectranthus amboinicus leaf extract mediated synthesis of zinc oxide nanoparticles and its control of methicillin resistant Staphylococcus aureusbiofilm and blood sucking mosquito larvae., Spectrochimica Acta Part A: Molecular and Biomolecular Spectroscopy.137, 886891.

[22] Y. ZHENG et al. (2015). Green biosynthesis of $\mathrm{SnO}_{2}$ nanoparticles by Plectranthus amboinicus leaf extract their photocatalytic activity toward Rhodamine B degradation., Journal of Ovonic Research., 11:1, 21 26.

[23] Y. Zheng et al. (2017).Biosynthesis of silver nanoparticles by Plectranthus amboinicus leaf extract 
and their catalytic activity towards methylene blue degradation. Revista Mexicana de IngenieríaQuímica.16:1 41-45.

[24] Poppy Anjelisa., ZaitunHasibuan., SumaiyahSumaiyah. (2019). The Anti-Proliferative and Pro-Apoptotic Properties of Ethanol Plectranthus amboinicus (Lour.) Spreng. Leaves Ethanolic Extract Nanoparticles on T47D Cell Lines., Asian Pacific Journal of Cancer Prevention, 20.

[25] Amarasiri, Attanayake, Jayatilaka and Mudduwa. (2018). Acute nephroprotective and antioxidant activities of aqueous leaf extract of Plectranthus amboinicus (Roxb.) grown in Sri Lanka., Journal of Pharmacognosy and Phytochemistry 7(4): 155-161

[26] Alvin Jose M, Ibrahim, Janardhanan S. (2005). Modulatory effect of Plectranthus amboinicus Lour. on ethylene glycol-induced nephrolithiasis in rats. Indian J Pharmacol. 37:4, 3-4.

[27] Yung-Jia Chiu, Tai-Hung Huang, Chuan-Sung Chiu, et al. (2012). "Analgesic and Antiinflammatory Activities of the Aqueous Extract from Plectranthus amboinicus (Lour.) Spreng. Both In Vitro and In Vivo," Evidence-Based Complementary and Alternative Medicine, 11.https://doi.org/10.1155/2012/508137.

[28] Ana Pavla A. DinizGurgel et al. (2009).In vivo study of the anti-inflammatory and antitumor activities of leaves from Plectranthus amboinicus(Lour.) Spreng (Lamiaceae)., Journal of Ethnopharmacology 125, 361-363.

[29] Shenoy S. et al. (2012). Hepatoprotective activity of Plectanthusamboinicus against paracetamol induced hepatotoxicity in rats. Int $\mathbf{J}$ Pharmacol and Clin Sci.1, 32-38.

[30] Patel R, Mahobia NK, Gendle R, Kaushik B, Singh SK. (2010). Diuretic activity of leaves of Plectranthus amboinicus (Lour) Spreng in male albino rats.Phcog Res, 2, 86-88.

[31] Roshan D. Patel et al. (2010). Antioxidant Potential of Leaves of Plectranthus amboinicus (Lour) Spreng., Der Pharmacia Lettre,2(4), 240-245.

[32] M. Rama Devi et al. (2010). Anti-gastric ulcer activity of Plectranthus amboinicus (Lour) in wistar albino rats.,J. Chem. Pharm. Res. 2(3), 374-380.

[33] K.Nirmala Devi et al. (2010). In vitro antiinflammatory activity of Plectranthus amboinicus (lour) spreng by hrbc membrane stabilization., IJPSR, $1: 1,26-29$.

[34] A. H. M. Viswanathaswamy, B. C. Koti, Aparna Gore, A. H. M. Thippeswamy, R. V. Kulkarni. (2011). Antihyperglycemic and Antihyperlipidemic Activity of Plectranthus amboinicus on Normal and AlloxanInduced Diabetic Rats. Indian J Pharm Sci. 73(2), 139_ 145.

[35] Archana CE. (2013). Antianxiety Effect of Alcoholic Leaf Extract of Plectranthus amboinicus in Mice.Asian Journal of Biomedical and Pharmaceutical Sciences, 3: $18,29-32$.

[36] Melva Silitonga et al. (2015). Levels of Apigenin and Immunostimulatory Activity of Leaf Extracts of Bangunbangun (Plectranthus amboinicusLour), International Journal of Biology; 7:1.
[37] José G.M. da Costa, Carla K.B. Pereira, Fabíola F.G. Rodrigues \& Sidney G. de Lima. (2010). Chemical Composition, Antibacterial and Fungicidal Activities of Leaf Oil of Plectranthus amboinicus (Lour.) Spreng.,Journal of Essential Oil Research, 22:2, 183185. DOI: 10.1080/10412905.2010.9700298.

[38] Barzaga Fernández, P.; TillánCapó, J.; Marrero Cofiño, G.; Carrillo Domínguez, C.; Bellma Menéndez, A.; Montero Alarcón, C. ; Editorial CienciasMedicas, Habana, Cuba, RevistaCubana de PlantasMedicinales.(2009). Expectorant activity of formulations from Plectrantusamboinicus (Lour) Spreng (French oregano).14:2.

[39] Leu W-J, Chen J-C and Guh J-H. (2019). Extract FromPlectranthus amboinicus Inhibit Maturation and Release of Interleukin $1 \beta$ Through Inhibition of NF- $\kappa B$ Nuclear Translocation and NLRP3 Inflammasome Activation. Front. Pharmacol. 10:573. doi: 10.3389/fphar.2019.00573.

[40] Sivaranjani D, Saranraj P, Manigandan M, Amala K.(2019). Antimicrobial activity of Plectranthus amboinicus solvent extracts against Human Pathogenic Bacteria and Fungi, Journal of Drug Delivery and Therapeutics. 9:3, 36-39. http://dx.doi.org/10.22270/jddt.v9i3.2604.

[41] T. Z. Ruan et al. (2019). Chemical constituents of the leaves ofPlectranthus amboinicus., Chemistry of Natural Compounds. 55:1.

[42] R. Vera et al. (1993). Chemical Composition of The Essential $\mathrm{OH}$ and Aqueous Extract of Plectranthus amboinicus. Planta Med. 59. 